\title{
First national-wide survey of trace elements in Cuban urban agriculture
}

\author{
Mirelys Rodríguez Alfaro $^{1}$ - Clístenes Williams Araújo do Nascimento ${ }^{2}$. \\ Olegario Muñiz Ugarte ${ }^{1}$. Alfredo Montero Álvarez ${ }^{3}$. \\ Adriana María de Aguiar Accioly ${ }^{4}$. Bernardo Calero Martín ${ }^{5}$. \\ Teudys Limeres Jiménez ${ }^{6}$. Milagros Ginebra Aguilar ${ }^{1}$
}

\begin{abstract}
Accepted: 16 June 2017 / Published online: 18 July 2017
\end{abstract}
(C) INRA and Springer-Verlag France SAS 2017

\begin{abstract}
Over the last three decades, urban agriculture has been improving food security in Cuba by providing fresh vegetables within and on the outskirts of cities and villages. However, organic fertilizers and substrates that are used in urban agriculture systems can be contaminated by trace elements and accordingly pose risks to human health. This study was carried out to measure the concentrations of cadmium, lead, arsenic, selenium, mercury, nickel, and chromium in composts and substrates used in Cuba's urban agriculture, as well as in vegetables grown in this cropping system to assess risks to human health. Extraction of trace elements from samples was performed with a mixture of nitric and hydrochloric acid in a microwave oven. Cadmium, lead, nickel, and chromium were determined via optical emission spectrometry, and mercury, selenium, and arsenic were measured using an atomic absorption spectrophotometer coupled with a hydride generation system. We demonstrated that the concentrations of trace elements in organic fertilizers, with the exception of
\end{abstract}

Clístenes Williams Araújo do Nascimento

clistenes.nascimento@ufrpe.br

1 Instituto de Suelos, Autopista Costa-Costa, km 81/2., Apdo. 8022, Capdevila, CP 10800 La Habana, Cuba

2 Departmento de Agronomia, Federal Rural University of Pernambuco (UFRPE), Dom Manuel de Medeiros street, s/n, Recife, PE 52171-900, Brazil

3 Centro de Aplicaciones Tecnológicas y Desarrollo Nuclear (CEADEN), La Habana, Cuba

4 Embrapa Cassava \& Tropical Fruits, Cruz Das Almas, Bahia, Brazil

5 Dirección Estatal de Suelos y Fertilizantes, Ministerio de la Agricultura, La Habana, Cuba

6 Instituto de Suelos, Dirección Provincial Guantánamo, Guantánamo, Cuba compost from municipal solid waste, were within permissible values and do not pose risks to human health. The compost produced from municipal solid waste and the substrates prepared with this material presented cadmium and lead concentrations above maximum permissible concentrations. This work represents the first national-wide survey of trace elements in Cuban urban agriculture. As a result of this investigation, the use of municipal-solidwaste compost for food production was forbidden in Cuba.

Keywords Agroecology $\cdot$ Food security $\cdot$ Sustainable agriculture $\cdot$ Heavy metals

\section{Introduction}

Agriculture in urban areas has become increasingly popular worldwide and is now an essential feature of urban planning in many cities owing to the variety of benefits it provides to urban settlements (Cruz et al. 2014; Vittori Antisari et al. 2015; Dieleman 2016). These benefits include improving access to healthy food, promoting social cohesion, creating opportunities for physical activities, improving urban economic well-being and revitalizing low-income communities (Angotti 2015). In developing countries, urban agriculture is chiefly a strategy for achieving food security. Urban gardeners generally have low incomes and need to grow vegetables for their food supply and as a source of income (Saumel et al. 2012).

Urban agriculture has been practiced in Cuba for the last three decades (Febles-González et al. 2011). This farming system is part of the renovation of Cuban agriculture that took place after the collapse of conventional agriculture following the fall of the socialist bloc in the 1990s and the intensification of the economic blockade. Given this situation, Cuban 
agriculture was reoriented toward cleaner production systems based on agroecology and organic practices (Fig. 1), which enable the incorporation of urban agriculture models into the farming system as a way of establishing food production in cities and villages, with important social, economic, and environmental benefits (Palma et al. 2015).

Due to the limited availability of resources and inputs such as mineral fertilizers and pesticides, urban agriculture in Cuba is highly dependent on the use of organic amendments, particularly composts (Rodríguez et al. 2011). The use of compost as fertilizer, soil conditioner, or substrate is a sustainable recycling practice due to its beneficial effects on the biological, physical, and chemical properties of the soil, as well as on plant growth (Mylavarapu and Zinati 2009). However, composting of municipal solid wastes may result in environmental risks depending on the trace-element concentration in the raw materials that are used, which makes the final use of the compost unsuitable for food production (Hargreaves et al. 2008; Sharif et al. 2016). Therefore, the ongoing monitoring of trace elements in composts is essential to guarantee an agroecological agriculture that protects human health and the environment (Nogales et al. 2014).

The primary concerns regarding the addition of trace elements to agriculture soils are the reduction of crop productivity due to phytotoxic effects, water pollution through leaching from soils, and the entry of these elements into the food chain following plant uptake. Trace elements can enter the human body via dust inhalation, dermal absorption, and ingestion of water, soil, and food grown in contaminated sites; ingestion of contaminated vegetables can represent up to $70 \%$ of the dietary intake of trace elements (Otte et al. 2001). These elements can also have a significant impact on soil microbiota, altering microbial activity and the metabolism of microorganisms (Bolaños et al. 2016; Hongyan et al. 2016; Muñiz 2008).

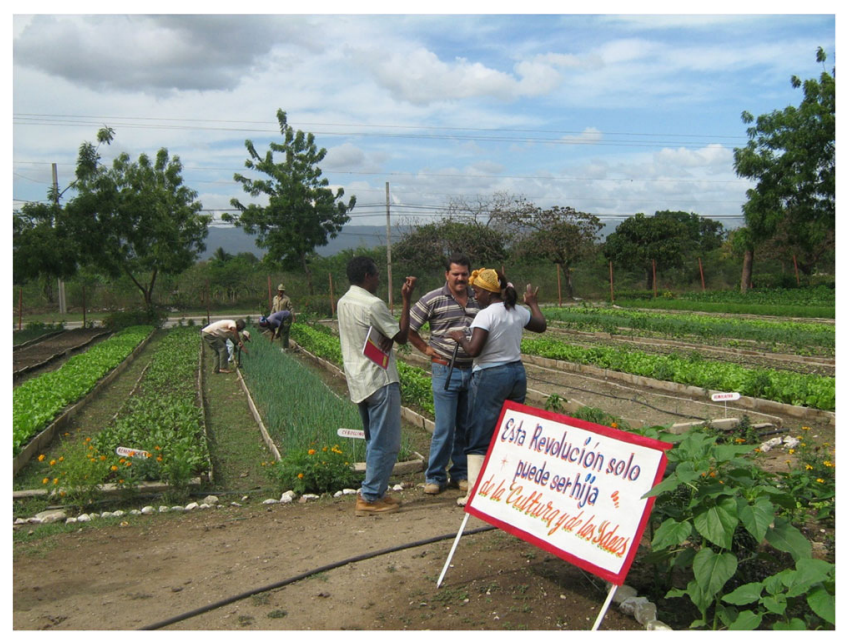

Fig. 1 Organic urban farm (organopónico) Jardín del Caribe, Guantánamo city, Cuba
There is a lack of information regarding human exposition to trace elements via urban agriculture in Cuba. We hypothesized that the uptake of trace elements via vegetables fertilized with some composts or substrates used in the country can pose a risk to human health. Therefore, the objectives of this work were to (1) determine the concentration of $\mathrm{Cd}, \mathrm{Pb}, \mathrm{Ni}, \mathrm{Zn}, \mathrm{Hg}$, $\mathrm{Se}$, and As in composts and substrates used in urban agriculture, (2) assess the uptake of $\mathrm{Cd}$ and $\mathrm{Pb}$ for vegetables cultivated in these substrates, and (3) evaluate the risks associated with the consumption of vegetables grown in urban agriculture. Our results can assist management authorities in eliminating or avoiding major metal sources in order to guarantee food quality and safety.

\section{Material and methods}

\subsection{Compost sampling and analysis}

We sampled 11 types of compost used for vegetable production on 60 organic urban farms (so-called organoponicos) and 11 waste-processing centers throughout Cuba. The composts were sampled in the following provinces: La Habana $(n=56)$, Guantanamo $(n=10)$, Pinar del Rio, Artemisa, Mayabeque, Matanzas, Villa Clara, Ciego de Avila, Camaguey, and Granma y Guantanamo $(n=11)$. The 10 composts sampled in Guantanamo were obtained from the waste-processing centers of Sur Isleta, Los Cocos, and Vilonio. The first two centers processes municipal solid waste without previous sorting that is then classified manually before forming the compost piles; the Vilonio waste center processes only crop residues.

Three composite samples were collected from each compost pile. Each composite sample was made up of 15 single samples collected randomly. The samples were air-dried and sieved through a 2-mm sieve. Eight replicates of each compost were analyzed for $\mathrm{pH}$, electric conductivity, and percentage of organic matter according to the methodology described in ISO-11464 (1999). The values' ranges were the following: $\mathrm{pH}(6.59-7.88)$, electric conductivity (1.09-7.45), and organic matter (39.3-69.5).

The composts were also analyzed for $\mathrm{Cd}, \mathrm{Pb}, \mathrm{Ni}, \mathrm{Zn}, \mathrm{Hg}$, $\mathrm{Se}$, and As. Owing to the absence of Cuban guideline values for trace elements in fertilizers, the values were compared with a Brazilian resolution that regulates the limits of these elements in organic fertilizers in order to protect soils and crops from contamination (Brasil 2006).

\subsection{Vegetable cultivation}

Four species of highly consumed vegetables in Cuba were analyzed for trace-element concentrations in their edible parts: lettuce (Lactuca sativa), chard (Beta vulgaris), radish (Raphanus sativus), and bell pepper (Capsicum annuum). 
These species were grown on four different substrates in single and successive croppings. These substrates were prepared with a 1:1 mixture of soil and either cow manure or municipalsolid-waste composts as commonly used in the organoponicos. Two soils were used. They were classified as Typic Kandiustalf (sandy loam texture) and Rhodic Eutrodox (clay texture) according to Soil Taxonomy (Soil Survey Staff 1999); these soil types are the primary agricultural soils in Cuba. Substrates with municipal-solid-waste compost were cultivated in two successive croppings: (1) lettuce followed by bell pepper and chard (Typic Kandiustalf) and (2) lettuce followed by radish and chard (Rhodic Eutrodox). Substrates with cow manure underwent a single cultivation of lettuce and chard.

For the substrates and vegetables, three composite samples made up of 20 subsamples zigzagged along each bed planting were taken. The vegetables were collected at commercial maturity. Samples of the leafy vegetables were divided into leaves and stems, and the bell pepper samples were separated into leaf, stem, and fruit parts. Vegetables were gently washed under running tap water and then rinsed with distilled water before analyses.

In order to assess the quality of vegetables produced on the substrates, the concentration of each trace element found in the edible parts of the studied vegetables was compared with the General Standard for Contaminants and Toxins in Food and Feed (Codex Alimentarius 2016).

\subsection{Chemical analyses}

Samples of soil, composts, substrates, and vegetables were digested in Teflon vessels with $9.0 \mathrm{~mL}$ of $\mathrm{HNO}_{3}$ and $3.0 \mathrm{~mL}$ of $\mathrm{HCl}$ in a microwave oven (USEPA 1998). High-purity acids were used in the analysis (Merck, PA). Glassware was cleaned and decontaminated in a 5\% nitric-acid solution for $24 \mathrm{~h}$ and then rinsed with distilled water. The concentrations of $\mathrm{Cd}, \mathrm{Pb}, \mathrm{Ni}$, and $\mathrm{Zn}$ were determined via inductively coupled plasma (ICP-OES/Optima 7000, Perkin Elmer), and the concentrations of $\mathrm{Hg}$, Se, and As were determined via atomic absorption coupled with a hydride generation system (FIAS100/Flow Injection System, Perkin Elmer).

Standard procedures for controlling the quality of the analysis, such as curve recalibration, analysis of blank samples, and analysis of standard reference material (NIST 2710 Montana Soil), were performed. The NIST recovery range of the evaluated metals was between 91 and $105 \%$.

\subsection{Statistical analysis}

Descriptive statistics (mean, medians, minimum and maximum values, and standard deviation) for the raw data were established using the statistical package Statgraphics Plus 5.1 (StatPoint, Inc., VA, USA). Due to the high variability of data, trace-element concentrations in the composts as well as the extreme values in individual populations of each element were standardized using a logarithmic transformation (ln (c) (MP) +1 ); this procedure was done for homogenization reasons to achieve a more symmetrical distribution and enable a comparable graphical representation.

\section{Results and discussion}

\subsection{Trace-element concentrations in composts and substrates}

In general, the concentration of trace elements in the studied composts was within the regulatory levels (Table 1), ensuring their safe use. However, trace-element contamination in municipal-solid-waste compost raises concerns about risks to human health; all of the elements assessed exceeded the permissible limits. The concentrations of $\mathrm{Cd}, \mathrm{Pb}, \mathrm{Hg}$, As, $\mathrm{Se}$, and Ni were roughly 3, 7, 2, 3,2, and 4 times higher, respectively, than permissible levels. The high level of $\mathrm{Ni}$ in the earthworm humus and in crop-residue compost is probably due to the unusually high natural concentration of $\mathrm{Ni}$ in soils of Cuba (Rodríguez et al. 2015). Municipal-solid-waste compost contains trace elements as a consequence of plastics, metal objects, solvents, paints, papers, wood and petroleum products, Cd-Ni batteries, and other discarded materials (Rodríguez et al. 2013). Separation of hazardous materials, such as batteries, at the source and central separation in mixed municipal solid-waste management systems could greatly decrease the trace-element concentration in the municipal-solid-waste compost (Zhang et al. 2008). However, the results indicated that the manual separation of significant trace-elementenriched materials was not effective at reducing the concentration of trace elements in the municipal-solid-waste compost.

A comparison of the trace-element concentrations of composts from municipal solid waste from Cuba and other countries corroborates the assertion that separation strategies must be improved in Cuban municipal solid-waste facilities in order to achieve lower trace-metal concentrations. The traceelement concentrations from municipal solid waste from Cuba were higher than found in municipal solid wastes from Brazil (Jordão et al. 2006), Tunisia (Achiba et al. 2009), Belgium (Soumaré et al. 2002), USA (Das et al. 2002), and Portugal (Alvarenga et al. 2007). The improvements to achieve lower metal concentrations include reducing or eliminating trace-element levels in materials destined to become municipal solid-waste compost, separating clean organic materials at the source for separate collection and composting, separating contaminants at the source for separate collection and disposal, separating contaminants from municipal solid waste at a centralized facility prior to composting, and 
Table 1 Trace-element mean values, standard deviation, and range for 11 composts sampled from organoponicos in Cuba and regulatory levels (RL) of trace elements in organic fertilizers. 1 filter-cake compost $(n=5)$, 2 horse manure + crop-residue compost $(n=6), 3$ horse manure + soil $1: 1(n=14), 4$ rabbit-manure compost $(n=1), 5$ cow-manure compost $(n=5), 6$ cow manure + crop-residue compost $(n=3), 7$ cow manure + soil - 1:1 $(n=5), 8$ earthworm humus $(n=5), 9$ crop-residue compost $(n=4), 10$ crop residue + soil $-1: 1(n=23), 11$ municipal-solid-waste compost $(n=6)$; Brasil (2006) ${ }^{\mathrm{a}}$

\begin{tabular}{|c|c|c|c|c|c|c|c|}
\hline \multirow[t]{2}{*}{ Compost } & \multicolumn{7}{|c|}{ Trace element $\left(\mathrm{mg} \mathrm{kg}^{-1}\right)$} \\
\hline & $\mathrm{Cd}$ & $\mathrm{Pb}$ & $\mathrm{Hg}$ & As & $\mathrm{Se}$ & $\mathrm{Ni}$ & $\mathrm{Cr}$ \\
\hline 1 & $0.7 \pm 0.1$ & $41.7 \pm 13.0$ & $0.02 \pm 0.00$ & $2.4 \pm 0.5$ & $3.3 \pm 0.8$ & $61.3 \pm 11.0$ & $40.0 \pm 5.0$ \\
\hline 2 & $0.7 \pm 0.5$ & $34.7 \pm 24.6$ & $0.03 \pm 0.02$ & $1.7 \pm 0.9$ & $3.6 \pm 2.9$ & $34.0 \pm 8.7$ & $40.3 \pm 15.2$ \\
\hline 3 & $0.7 \pm 0.5$ & $45.4 \pm 31.0$ & $0.02 \pm 0.01$ & $3.0 \pm 2.1$ & $4.3 \pm 3.2$ & $58.9 \pm 24.5$ & $47.8 \pm 19.4$ \\
\hline 4 & $0.5 \pm 0.0$ & $34.9 \pm 0.0$ & $0.03 \pm 0.00$ & $2.9 \pm 0.0$ & $2.8 \pm 0.0$ & $46.9 \pm 0.0$ & $52.1 \pm 0.0$ \\
\hline 5 & $0.8 \pm 0.5$ & $34.9 \pm 6.4$ & $0.03 \pm 0.02$ & $1.4 \pm 0.9$ & $5.7 \pm 4.7$ & $60.2 \pm 22.0$ & $57.6 \pm 21.2$ \\
\hline 6 & $0.9 \pm 0.8$ & $58.4 \pm 0.8$ & $0.04 \pm 0.02$ & $1.2 \pm 0.0$ & $2.8 \pm 0.0$ & $26.0 \pm 0.0$ & $33.7 \pm 8.0$ \\
\hline 7 & $1.5 \pm 0.2$ & $48.0 \pm 12.5$ & $0.04 \pm 0.01$ & $2.7 \pm 1.57$ & $3.8 \pm 0.4$ & $62.7 \pm 11.2$ & $113.0 \pm 3.5$ \\
\hline 8 & $1.0 \pm 0.5$ & $47.8 \pm 17.8$ & $0.06 \pm 0.04$ & $14.9 \pm 2.17$ & $4.3 \pm 2.0$ & $160.4 \pm 45.4$ & $152.6 \pm 40.9$ \\
\hline 9 & $0.4 \pm 0.1$ & $61.9 \pm 7.4$ & $0.02 \pm 0.00$ & $14.3 \pm 2.8$ & $2.5 \pm 0.8$ & $150.9 \pm 21.5$ & $177.0 \pm 15.0$ \\
\hline 10 & $0.7 \pm 0.3$ & $45.0 \pm 7.2$ & $0.03 \pm 0.02$ & $16.3 \pm 2.8$ & $4.3 \pm 0.8$ & $206.4 \pm 97.5$ & $176.4 \pm 34.8$ \\
\hline 11 & $4.8 \pm 0.9$ & $545.2 \pm 93.8$ & $1.90 \pm 0.63$ & $62.1 \pm 2.0$ & $141.0 \pm 42.1$ & $253.3 \pm 26.5$ & $221.7 \pm 46.4$ \\
\hline Range & $0.2-6.2$ & $13.5-1.1$ & ND-2.8 & ND-98.0 & $0.8-204$ & $10.6-455.7$ & $16.7-297.3$ \\
\hline$R L^{\mathrm{a}}$ & 3 & 150 & 1 & 20 & 80 & 70 & 200 \\
\hline
\end{tabular}

separating contaminants from municipal-solid-waste compost at a centralized facility after composting (Richard and Woodbury 1992).

The concentrations of trace elements in soils and substrates that did not receive municipal-solid-waste compost were within permissible levels for agricultural soils (Table 2), except for $\mathrm{Ni}$ and $\mathrm{Cr}$. The high concentrations of $\mathrm{Ni}$ and $\mathrm{Cr}$ in Cuban soils are natural and inherent to the parent soil material (Rodríguez et al. 2015). On the other hand, the use of municipal-solid-waste compost increased the concentrations of $\mathrm{Cd}, \mathrm{Pb}, \mathrm{As}, \mathrm{Se}$, and $\mathrm{Hg}$ above the limits considered safe for soil cultivation. Achiba et al. (2009) also reported that the addition of municipal-solid-waste compost increased $\mathrm{Cd}$ and $\mathrm{Pb}$ concentrations in the soil.

\subsection{Cadmium and lead concentrations in vegetables}

The Codex Alimentarius (2016) presents threshold values only for $\mathrm{Cd}$ and $\mathrm{Pb}$; other trace elements were not determined in the edible parts of crops. The concentrations of $\mathrm{Cd}$ and $\mathrm{Pb}$ in the edible parts of vegetables grown on substrates that received cow manure (Fig. 2) were below the maximum allowable concentration of these elements (Codex Alimentarius 2016). Therefore, the cow manure used in Cuban urban

Table 2 Trace-element concentrations in soils and substrates (soil + organic fertilizer/compost, 1:1 ratio) used in Cuban urban agriculture. Mean of three replicates. TK Typic Kandiustalf, RE Rhodic Eutrodox, MSWC municipal-solid-waste compost, $P L$ permissible level in soils ${ }^{\text {a }}$ (CONAMA 2009) and substrates ${ }^{\mathrm{b}}$ (Brasil 2006)

\begin{tabular}{|c|c|c|c|c|c|c|c|}
\hline \multirow[t]{2}{*}{ Substrate } & \multicolumn{7}{|c|}{ Trace-element concentration ( $\mathrm{mg} \mathrm{kg}^{-1}$ ) } \\
\hline & $\mathrm{Cd}$ & $\mathrm{Pb}$ & As & $\mathrm{Se}$ & $\mathrm{Hg}$ & $\mathrm{Ni}$ & $\mathrm{Cr}$ \\
\hline TK soil & $0.8 \pm 0.1$ & $24.3 \pm 4.3$ & $15.1 \pm 1.1$ & $1.3 \pm 0.1$ & $0.07 \pm 0.0$ & $183.0 \pm 9.6$ & $191.9 \pm 12.6$ \\
\hline RE soil & $0.4 \pm 0.1$ & $36.9 \pm 5.0$ & $6.2 \pm 0.9$ & $1.4 \pm 0.2$ & $0.03 \pm 0.0$ & $276.5 \pm 8.8$ & $154.9 \pm 16.2$ \\
\hline TK + Cow Manure & $0.4 \pm 0.1$ & $66.5 \pm 7.1$ & $18.0 \pm 4.3$ & $2.4 \pm 0.1$ & $0.07 \pm 0.0$ & $178 \pm 10.0$ & $179 \pm 14.6$ \\
\hline RE + Cow Manure & $0.4 \pm 0.1$ & $98.1 \pm 9.1$ & $19.4 \pm 6.2$ & $1.4 \pm 0.8$ & $0.07 \pm 0.0$ & $186 \pm 7.6$ & $198 \pm 12.2$ \\
\hline $\mathrm{TK}+\mathrm{MSWC}$ & $9.1 \pm 1.0$ & $352.0 \pm 12.1$ & $62.4 \pm 9.1$ & $143.1 \pm 8.1$ & $12.45 \pm 1.08$ & $285 \pm 8.8$ & $245.2 \pm 23.1$ \\
\hline $\mathrm{RE}+\mathrm{MSWC}$ & $8.6 \pm 0.9$ & $1501.5 \pm 23.2$ & $75.8 \pm 12.1$ & $149.0 \pm 12.2$ & $14.09 \pm 1.37$ & $298 \pm 9.5$ & $228.4 \pm 32.0$ \\
\hline$P L^{\mathrm{a}}$ & 3 & 180 & 35 & 5 & 12 & 100 & 150 \\
\hline$P L^{\mathrm{b}}$ & 8 & 300 & 20 & 80 & 2.5 & 175 & 500 \\
\hline
\end{tabular}


Fig. 2 Concentrations of cadmium (a) and lead (b) in edible parts of lettuce and chard grown on the substrate with cow manure. TC threshold concentration (Codex Alimentarius 2016)

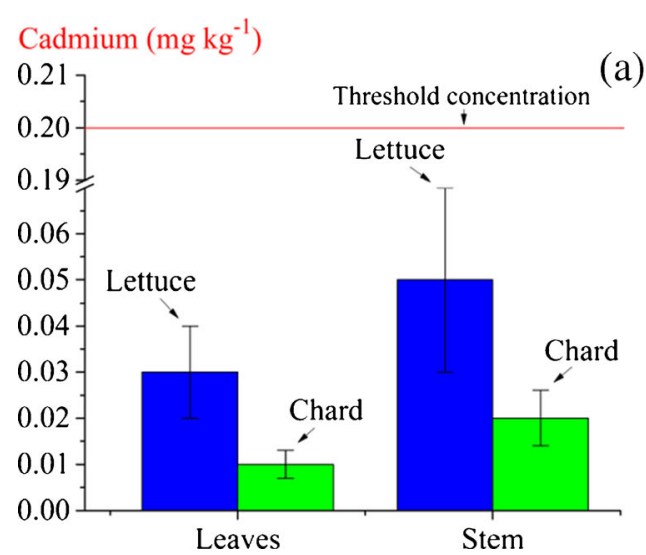

Lead $\left(\mathrm{mg} \mathrm{kg}^{-1}\right)$

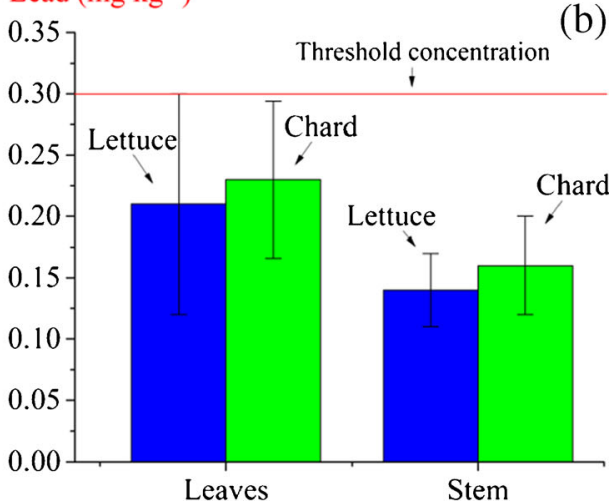

\section{)}

agriculture does not pose risks regarding the uptake of $\mathrm{Cd}$ and $\mathrm{Pb}$ by vegetables. Clemente et al. (2007) reported that cow manure did not change the available concentrations of trace elements in soil or their uptake by plants compared with controls. In general, cow manure presents low concentrations of potentially toxic elements, and it can even be used to alleviate phytotoxicity

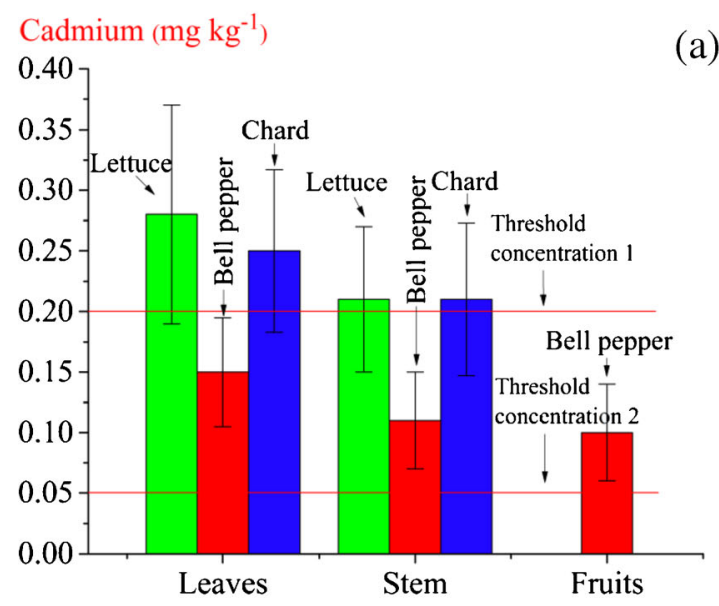

Cadmium $\left(\mathrm{mg} \mathrm{kg}^{-1}\right)$

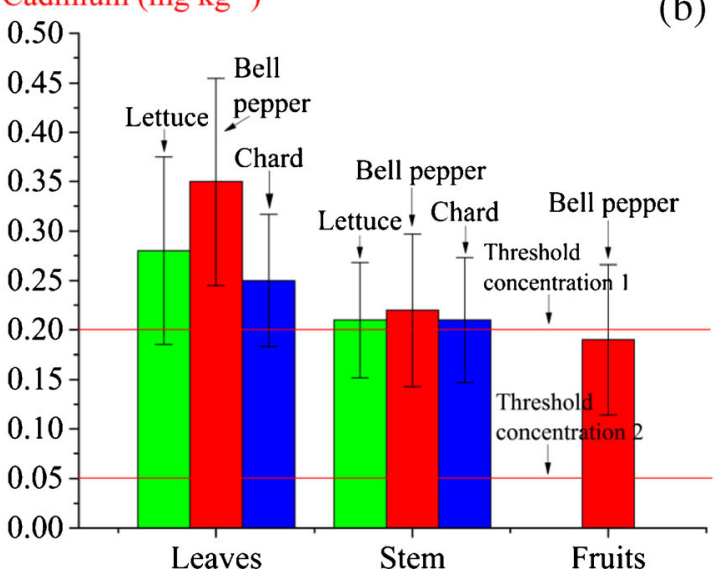

Fig. 3 Concentration of cadmium (a and $\mathbf{c}$ ) and lead (b and $\mathbf{d}$ ) in edible parts of vegetables grown successively (lettuce - bell pepper - chard and lettuce-radish — chard) on substrate with municipal-solid-waste and trace-element uptake in plants (Rehman et al. 2016).

We found that the use of municipal-solid-waste compost obtained from the three waste-processing centers studied poses a serious risk to human health due to the transfer of trace elements present in the municipal-solid-waste compost (Table 1) into the edible parts of vegetables cultivated in

Lead $\left(\mathrm{mg} \mathrm{kg}^{-1}\right)$

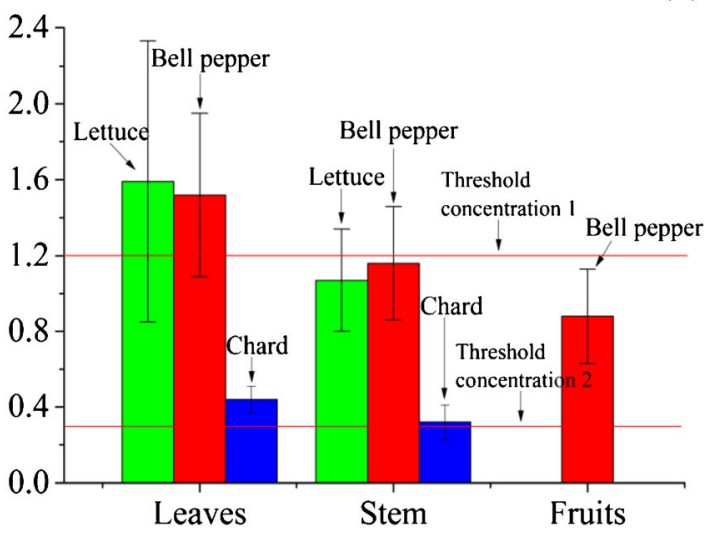

Lead $\left(\mathrm{mg} \mathrm{kg}^{-1}\right)$

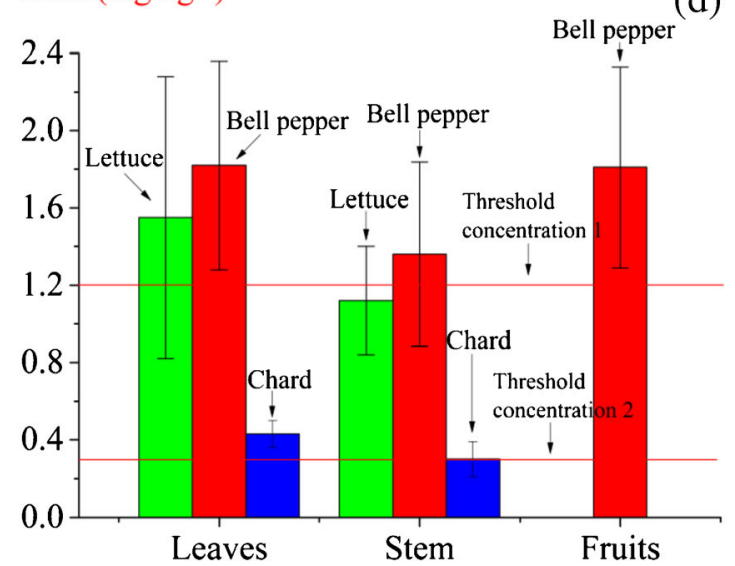

compost. $T C$ (1) and $T C$ (2) threshold concentration in leaves and fruits, respectively (Codex Alimentarius 2016) 
successive cropping: lettuce, bell pepper, and chard (Fig. 3a, b) and lettuce, radish, and chard (Fig. 3c, d).

In all cases, the highest concentrations of $\mathrm{Cd}$ and $\mathrm{Pb}$ were observed in leaves. With the exception of bell pepper fruits, the lowest metal concentrations were found in plant stems. However, the concentrations of $\mathrm{Cd}$ and $\mathrm{Pb}$ in leaves of lettuce and chard and the fruits of bell peppers were above the permissible limits set by the Codex Alimentarius, which renders these edible parts unsuitable for human consumption. Murray et al. (2011) also reported unacceptably high concentrations of $\mathrm{Cd}$ and $\mathrm{Pb}$ in lettuce and green-bean pods grown on soils amended with compost consisting of decomposed clippings and leaves collected from lawns and flower gardens. Lima et al. (2015) reported that the $\mathrm{Pb}$ concentrations in the edible parts of vegetables cultivated in a soil contaminated by battery recycling wastes were similar to the concentrations found in this work and also above threshold limits. It is important to point out that unacceptably high concentrations of $\mathrm{Pb}$ and $\mathrm{Cd}$ associated with municipal-solid-waste compost application in our work were observed in leaves and fruits harvested, even in the third cropping. This fact clearly highlights the potential health risks associated with the use of such composts for food production.

\section{Conclusions}

Given the reorientation of Cuban agriculture toward cleaner production systems based on agroecological practices, it is of paramount importance to assess the concentration of trace elements in organic agricultural inputs used in Cuba. Our data indicated that the concentrations of $\mathrm{Cd}, \mathrm{Pb}, \mathrm{As}, \mathrm{Se}, \mathrm{Hg}, \mathrm{Ni}$, and $\mathrm{Cr}$ in organic fertilizers used for composting in Cuban urban agriculture (filter cake, horse manure, rabbit manure, cow manure, crop residue, and earthworm humus) were within permissible limits. Therefore, these fertilizers do not constitute a risk to human health. On the other hand, composts produced from municipal solid waste yielded values above the permissible concentrations in organic fertilizers for all of the trace elements that we studied. Plants cultivated with municipal-solid-waste composts absorbed $\mathrm{Cd}$ and $\mathrm{Pb}$ in concentrations higher than the limits considered safe for human health. As a result of our study, municipal-solidwaste composts have been forbidden by Cuban authorities for food production until strategies to achieve lower trace-element concentrations in municipal-solid-waste compost from wasteprocessing centers are implemented.

\section{References}

Achiba WB, Gabteni N, Lakhdar A, Laing GD, Verloo M, Jedidi N, Gallali T (2009) Effects of 5-year application of municipal solid waste compost on the distribution and mobility of heavy metals in a Tunisian calcareous soil. Agric Ecosyst Environ 130:156-163. doi:10.1016/j.agee.2009.01.001

Alvarenga P, Palma P, Gonçalves AP, Fernandes RM, Cunha-Queda AC, Duarte E, Vallini G (2007) Evaluation of chemical and ecotoxicological characteristics of biodegradable organic residues for application to agricultural land. Environ Inter 33:05-513. doi:10.1016/j. envint.2006.11.006

Angotti T (2015) Urban agriculture: long-term strategy or impossible dream? Lessons from prospect farm in Brooklyn, New York. Public Health 129:336-341. doi:10.1016/j.puhe.2014.12.008

Bolaños Y, Alonso CM, Morabito R, Díaz M, Pinto V, Gómez M (2016) Mercury contamination of riverine sediments in the vicinity of a mercury cell chlor-alkali plant in Sagua River, Cuba. Chemosphere 152:376-382. doi:10.1016/j.chemosphere.2016.03. 025

BRASIL (2006) Ministério da Agricultura, Pecuária e Abastecimento. Métodos físico-químicos e físicos oficiais de fertilizantes orgânicos, organo-minerais, minerais e corretivos. Available at: $<$ http://www.agricultura.gov.br>. Acceessed June 2012

Clemente R, Paredes C, Bernal MP (2007) A field experiment investigating the effects of olive husk and cow manure on heavy metal availability in a contaminated calcareous soil from Murcia (Spain). Agric Ecosyst Environ 118:319-326. doi:10.1016/j.agee.2006.06.002

Codex Standard 193-1995 (2016) General Standard for contaminants and toxins in food and feed. $65 \mathrm{p}$

CONAMA-Conselho Nacional do Meio Ambiente (2009) Resolução no 420, de 28 de dezembro de 2009. Diário Oficial da República Federativa do Brasil Brasília, DF, $n^{\circ} 249$, de 30/12/2009, 8184p. $\mathrm{http}: / /$ www.mma.gov.br/port/conama/legiano1.cfm? codlegitipo= 3\&ano=2009. Accessed 23 Apr 2013

Cruz N, Rodrigues SM, Coelho C, Carvalho L, Duarte AC, Pereira E, Romkens PFAM (2014) Urban agriculture in Portugal: availability of potentially toxic elements for plant uptake. Appl Geochem 44: 27-37. doi:10.1016/j.apgeochem.2013.07.003

Das KC, Smith MC, Gattie DK, Boothe DDH (2002) Stability and quality of municipal solid waste compost from a landfill aerobic bioreduction process. Adv Environ Res 6:401-409. doi:10.1016/ S1093-0191(01)00066-1

Dieleman H (2016). Urban agriculture in Mexico City; balancing between ecological, economic, social and symbolic value. J Clean Prod In Press. doi:10.1016/j.jclepro.2016.01.082

Febles-González JM, Tolón-Becerra A, Lastra-Bravo X, Acosta-Valdés X (2011) Cuban agricultural policy in the last 25 years. From conventional to organic agriculture. Land Use Policy 28:723-735. doi:10. 1016/j.landusepol.2010.12.008

Hargreaves JC, Adl MS, Warman PR (2008) A review of the use of composted municipal solid waste in agriculture. Agric Ecosyst Environ 123:1-14. doi:10.1016/j.agee.2007.07.004

Hongyan C, Xuyin Y, Tianyuan L, Sun H, Junfeng J, Cheng W (2016) Characteristics of heavy metal transfer and their influencing factors in different soil-crop systems of the industrialization region, China. Ecotox Environ Safe 126(16):193-201. doi:10.1016/j.ecoenv.2015. 12.042

ISO-11464 (1999) Soil Quality. Preliminary preparation of samples for physico-chemical analysis [In Spanish]

Jordão CP, Nascentes CC, Cecon PR, Fontes RLF, Pereira JL (2006) Heavy metal availability in soil amended with composted urban solid wastes. Environ Monit Assess 112:309-326. doi:10.1007/ s10661-006-1072-y

Lima FS, Nascimento CWA, Souza CS (2015) Lead and nutrient allocation in vegetables grown in soil from a battery site. Sem Ci Agr 36: 2483-2491. doi:10.5433/1679-0359.2015v36n4p2483

Muñiz O (2008) Los microelementos en la agricultura. Editorial Agroinfor. $132 \mathrm{p}$

Murray H, Pinchin TA, Macfie SM (2011) Compost application affects metal uptake in plants grown in urban garden soils and potential 
human health risk. J Soils Sediments 11:815-829. doi:10.1007/ s11368-011-0359-y

Mylavarapu RS, Zinati GM (2009) Improvement of soil properties using compost for optimum parsley production in sandy soils. Sci Hortic 120:426-430. doi:10.1016/j.scienta.2008.11.038

Nogales R, Romero E, Fernandez MJ (2014) De Residuo a Recurso. El Camino hacia la sostenibilidad. Ediciones Mundi-Prensa, Madrid $172 \mathrm{p}$

Otte PF, Lijzen JPA, Swartjes FA, Versluijs CW (2001) Evaluation and revision of the CSOIL parameter set. Report 711701021. RIVM, Bilthoven

Palma IP, Toral JN, Vázquez MRP, Fuentes NF, Hernández FG (2015) Historical changes in the process of agricultural development in Cuba. J Clean Prod 96:77-84. doi:10.1016/j.jclepro.2013.11.078

Rehman MZ, Rizwan M, Ali S, Fatima N, Yousaf B, Naeem A, Sabir M, Ahmad HR, Ok YS (2016) Contrasting effects of biochar, compost and farm manure on alleviation of nickel toxicity in maize (Zea mays L.) in relation to plant growth, photosynthesis and metal uptake. Ecotox Environ Safe 133:218-225. doi:10.1016/j.ecoenv.2016.07. 023

Richard TL, Woodbury PB (1992) The impact of separation on heavy metal contaminants in municipal solid waste composts. Biomass Bioenergy 3(3-4):195-211. doi:10.1016/0961-9534(92)90026-M

Rodríguez A, Companioni N, Peña E, Prades FC, Buides JF, Ortiz JE (2011) Manual técnico para Organopónicos, Huertos Intensivos y Organoponía semiprotegida. $184 \mathrm{p}$

Rodríguez M, Muñiz O, Calero BJ, Montero AF, Limeres T, Orphee M (2013) Metales pesados en abonos orgánicos y sustratos utilizados para producir hortalizas. En Libro de Edición Argentina, editado por Editorial MNEMOSYNE en abril de 2013. Buenos Aires. 989 p
Rodríguez M, Montero A, Muñiz O, Nascimento CWA, Accioly AMA, Biondi CM, Silva YJAB (2015) Background concentrations and reference values for heavy metals in soils of Cuba. Environ Monit Assess 187:4198-4208. doi:10.1007/s10661-014-4198-3

Saumel I, Kotsyuk I, Holscher M, Lenkereit C, Weber F, Kowarik I (2012) How healthy is urban horticulture in high traffic areas? Trace metal concentrations in vegetable crops from plantings within inner city neighbourhoods in Berlin, Germany. Environ Pollut 165: 124-132. doi:10.1016/j.envpol.2012.02.019

Sharif Z, Hossaini SMT, Renella G (2016) Risk assessment for sediment and stream water polluted by heavy metals released by a municipal solid waste composting plant. J Geochem Explor 169:202-210

Soil Survey Staff (1999) Soil Taxonomy, Second edition. USDA-NRCS, Agriculture Handbook No.436

Soumaré M, Demeyer A, Tack FMG, Verloo M (2002) Chemical characteristics of Malian and Belgian solid waste composts. Bioresour Technol 81:97-101. doi:10.1016/S0960-8524(01)00125-0

USEPA-UNITED STATES ENVIRONMENTAL PROTECTION AGENCY (1998) Method 3051a. Microwave assisted acid digestion of sedments, sludges, soils, and oils. http:/www.epa.gov/ epawaste/hazard/testmethods/sw846/pdfs/3051a.pdf〉 Access 14 Feb 2010

Vittori Antisari L, Orsini F, Marchetti L, Vianello G, Gianquinto G (2015) Heavy metal accumulation in vegetables grown in urban gardens. Agron Sustain Dev 35:1139-1147. doi:10.1007/s13593-015-0308-z

Zhang H, He PJ, Shao LM (2008) Implication of heavy metals distribution for a municipal solid waste management system - a case study in Shanghai. Sci Total Environ 402:257-267. doi:10.1016/j. scitotenv.2008.04.047 